\title{
Premature subclinical atherosclerosis in children and young adults with juvenile idiopathic arthritis. A review considering preventive measures
}

\author{
Anna-Helene Bohr ${ }^{1 *}$, Robert C. Fuhlbrigge ${ }^{2}$, Freddy Karup Pedersen ${ }^{3}$, Sarah D. de Ferranti ${ }^{2}$ and Klaus Müller $^{4}$
}

\begin{abstract}
Many studies show that Juvenile Idiopathic Arthritis (JIA) is associated with early subclinical signs of atherosclerosis. Chronic inflammation per se may be an important driver but other known risk factors, such as dyslipidemia, hypertension, insulin insensitivity, a physically inactive lifestyle, obesity, and tobacco smoking may also contribute substantially. We performed a systematic review of studies through the last 20 years on early signs of subclinical atherosclerosis in children and adolescents with JIA with the purpose of investigating whether possible risk factors, other than inflammation, were considered.

We found 13 descriptive cross sectional studies with healthy controls, one intervention study and two studies on adults diagnosed with JIA. Only one study addressed obesity, and physical activity (PA) has only been assessed in one study on adults with JIA and only by self-reporting. This is important as studies on PA in children with JIA have shown that most patients are less physically active than their healthy peers, and as physical inactivity in several large studies of normal schoolchildren is found to be associated with increased clustering of risk factors for cardiovascular disease. It is thus possible that an inactive lifestyle in patients with JIA is an important contributor to development of the subclinical signs of atherosclerosis seen in children with JIA, and that promotion of an active lifestyle in childhood and adolescence may diminish the risk for premature atherosclerotic events in adulthood.
\end{abstract}

Keywords: Juvenile idiopathic arthritis, Chronic arthritis, Premature atherosclerosis, Adipositas, BMI, Physical activity, Tobacco smoking, Prevention of atherosclerosis

\section{Background}

Juvenile Idiopathic Arthritis (JIA) is the collective term for a clinically diverse group of rheumatic inflammatory syndromes of unknown etiology, which may present as a systemic inflammation, an isolated arthritis or in association with other organ specific inflammatory disorders such as psoriasis and uveitis. The annual incidence in the Western world is $16-150$ per 100.000 children, making it the most common chronic inflammatory disease in childhood [1]. Several phenotypes are recognized, ranging from self-limiting forms involving a few joints, to erosive polyarthritis and systemic JIA (sJIA), all of a

\footnotetext{
* Correspondence: anna-helene.bohr@regionh.dk

'Department of Paediatrics and Adolescent Medicine, JMC Research Unit, Rigshospitalet Afs. 7821, Tagensvej 22, DK 2200 Copenhagen N, Denmark

Full list of author information is available at the end of the article
}

relapsing and remitting nature. Although some patients enter spontaneous permanent remission, $41-78 \%$ of patients require continuous or recurrent treatment in adulthood [1-4]. JIA is thus a long lasting chronic inflammatory disease, and concern has been raised, as in rheumatoid arthritis (RA), regarding the risk of premature development of cardiovascular disease. Indeed, several studies of children with JIA have described the occurrence of early subclinical signs of atherosclerosis.

Family disposition for cardiovascular disease, dyslipidemia, hypertension, and diabetes, as well as lifestyle factors such as obesity, physical inactivity, and tobacco smoking are known individually significant risk factors for accelerated development of atherosclerosis; cohort studies of the general population such as Framingham Heart Study [5] and Young Finns [6, 7] have helped in 
identifying these factors. More recently the concept has emerged that chronic systemic inflammation may also contribute. This is based primarily on large cohort studies of patients with RA. For example, a meta-analysis of mainly community based cohorts and case-control studies of incident cardiovascular events including myocardial infarction, cerebrovascular accidents and congestive heart failure in 41,490 patients with RA indicates an increase in risk of about fifty percent compared with the general population [8]. Likewise treating to the lowest possible levels of disease activity has been shown to reduce the risk for cardiovascular events in patients with RA [9].

However, focusing too narrowly on persistent inflammation as a driver for the development of atherosclerosis risks overlooking equally important, and potentially reversible, risk factors; this is well-illustrated in a recent report on progression of atherosclerosis in patients with RA by del Rincón et al. [10]. For this reason we reviewed existing studies reporting early or subclinical signs of cardiovascular disease in children with JIA to see whether known risk factors were taken into account.

Studies published in English were searched through PubMed (National Library of Medicine), primarily making use of MeSH terms and free text and secondarily by following key references in relevant articles. Studies from the last 20 years are included, as this covers a period of more efficacious treatment for JIA.

\section{Risk for development of premature atherosclerosis in childhood and adolescence}

Acquired overt cardiovascular disease is rare during childhood. However, post mortem studies of the vasculature of apparently healthy children and young adults, 2 to 39 years of age, have shown that microscopic lipid deposits and inflammatory reactions, the hallmark of atherosclerosis, are found in the arterial intima of infants and young children and that fatty streaks and fibrous plaques are seen in the aorta and coronary arteries of most teen-agers [11-14], suggestive of atherosclerosis as a continuing process beginning early in life. The natural history of the arterial lesions was investigated through studies at the same location in the arterial tree across different age groups. Progression to more severe atherosclerosis was associated with raised levels of the nonHigh-Density-Lipoprotein fraction of cholesterol (noncHDL) in blood, hypertension, impaired glucose tolerance, obesity, and tobacco smoking, with each factor reinforcing the others [15].

In addition there is mounting evidence for the importance of physical activity (PA) for continuing cardiovascular health through childhood, adolescence and adulthood [16-21]. Indeed, being physically active is one of the seven ideal metrics for continuing cardiovascular health issued by the American Heart Association [22], the other six metrics being non-smoking, keeping a healthy diet, maintaining normal blood pressure, normal glucose- and lipid-metabolism, and normal weight.

Large longitudinal observational population-based studies beginning in childhood or adolescence confirm the association with structural or functional vascular changes in adulthood, indicative of future clinically important cardiovascular disease [6, 23-28] (Table 1).

\section{Surrogate markers of preclinical atherosclerosis}

In adults, several non-invasive techniques for evaluation of endothelial function and structural changes in the arterial wall have proven reliable markers for later development of acute cardiovascular events and are now included in many clinical studies as surrogate markers of atherosclerosis.

In a Scientific Statement from the American Heart Association, Urbina et al. review assessment of subclinical atherosclerosis in children and adolescents by these techniques [29].

A short description of the non-invasive methods used in investigations of cardiovascular function in JIA is given in Table 2, together with relevant references.

As well-defined atherosclerotic events like myocardial infarcts and stroke are very rare in childhood, the prognostic value of the described abnormalities must await clinical studies reaching into mid-late adulthood. Nevertheless the association established between the structural and functional surrogate markers of early atherosclerosis and the above-mentioned known risk factors for development of clinical overt atherosclerosis [6] make these simple and non-invasive techniques attractive as tools in studies of cardiovascular health in children with JIA.

At present, there are no available prognostic biomarkers in the blood with acceptable sensitivity and specificity for subclinical cardiovascular disease [30, 31].

\section{Investigations of cardiovascular structure and function in children and adolescents with JIA}

Although severe extra-articular complications may occur in the acute phase of systemic JIA (sJIA), including

Table 1 Known risk factors in childhood and adolescence for premature development of cardiovascular disease

\section{Family disposition}

Hypertension

Hypercholesterolemia, dyslipidemia

Insulin resistance

Obesity

Physical inactivity

Smoking

References given in the text 
Table 2 Non-invasive methods for investigation of cardiovascular function

\begin{tabular}{|c|c|c|c|}
\hline Measurement & Abbreviation & Principle & References \\
\hline Coronary artery calcification & CAC & Arterial wall structure, atherosclerotic plaques & {$[7,29,37]$} \\
\hline $\begin{array}{l}\text { Intimal and Medial thickness of the wall in } \\
\text { carotis or aorta }\end{array}$ & $\begin{array}{l}\text { CIMT (carotis), alMT } \\
\text { (aorta) }\end{array}$ & Arterial wall structure & $\begin{array}{l}{[21,26,29,} \\
71]\end{array}$ \\
\hline Left ventricle mass index & LVMi & $\begin{array}{l}\text { Left ventricular dimensions adjusted for height, weight, age, and } \\
\text { sex }\end{array}$ & {$[32]$} \\
\hline Pulse wave velocity & PW & Direct measure of stiffness in large arteries & $\begin{array}{l}{[29,37,72,} \\
73]\end{array}$ \\
\hline Augmentation index & Alx & $\begin{array}{l}\text { Indirect measure of arterial stiffness combining arterial and } \\
\text { ventricular function }\end{array}$ & {$[29,37,73]$} \\
\hline Flow mediated dilation & FMD & Endothelial cell function & $\begin{array}{l}{[29,71,} \\
74-76]\end{array}$ \\
\hline Glyceryl trinitrate mediated flow & GTN-mediated dilation & Arterial wall function & [71] \\
\hline Arterial distensibility & & Direct measure of stiffness in large arteries & {$[29,71]$} \\
\hline Plasma natriuretic peptide & NT-pro-BNP & Ventricular dysfunction & [77] \\
\hline Troponin T & TnT & Myocardial damage & [77] \\
\hline
\end{tabular}

serositis, myocarditis, renal amyloidosis, and cerebral vasculitis, there is no evidence of cardiac and cardiovascular involvement as common clinical features in the chronic phase of JIA during childhood and adolescence. However, JIA is a chronic inflammatory disease, and concern regarding premature development of cardiovascular disease, as seen in patients with RA, has led to performance of echocardiographic and tonometric studies, as well as studies on endothelial function in children and young adults with JIA with no clinical signs of cardiovascular dysfunction and with no family disposition for cardiovascular disease (Table 3).

In the available cross-sectional studies measuring signs of early atherosclerosis in JIA, life style risk factors for development of premature atherosclerosis were not, in general, considered systematically. Lipids were measured in several studies and showed no consistent pattern, but only one study specifically addressed overweight status [32]. None of the studies took PA into consideration.

There is, at present, only one intervention study [33, 34] that has examined the effect of anti-inflammatory treatment on cIMT. In a group of prepubertal patients with oligo- and polyarticular JIA, with a control group only at baseline, cIMT was found to be significantly increased in JIA patients at enrolment, with a significant decrease documented after 1 year of anti-inflammatory medication, (NSAID, MTX, Etanercept). Treatment was also correlated with a significant reduction in diastolic and systolic blood pressure and an improvement in inflammatory markers and lipids. Lifestyle was not documented, however, leaving open the possibility that the cardiovascular improvement was due to a healthier, more active lifestyle which might have occurred in parallel with decreasing disease activity.
Prospective long-term studies of JIA have focused on the prevalence and severity of arthritis and the impact on musculoskeletal function; only few studies report data on cardiovascular health in adults with a history of JIA [35-37]. Raab et al. [36] collected information from adult patients with JIA treated with biologics. Cardiovascular disease, mainly arterial hypertension, was reported in a total of $9.9 \%$, a proportion similar to that seen in an age and gender matched control group drawn from a community sample. However, a disproportionally high rate was noted in patients with a history of sJIA, where 6 out of 15 patients reported hypertension; 2/3 of the patients with sJIA received treatment with corticosteroids.

Aulie et al. [37] examined arterial stiffness by use of PWV and AIx in a 29-year follow up study of young adults diagnosed with JIA and still having active disease. These authors found a small, but significant, increase in arterial stiffness by PWV associated with elevated diastolic blood pressure. AIx was not significantly different from controls but was negatively correlated with markers of active disease, use of prednisolone, self-reported lower PA, and daily smoking. Coronary artery calcification was also not more frequent in young adults with JIA than in the general population, but was positively correlated with waist circumference, BMI, systolic blood pressure, blood glucose and daily prednisolone. Insulin resistance was increased in the patients as was, unexpectedly, the frequency of daily smoking. The study by Aulie et al. [37] is the only report in which all known risk factors for atherosclerosis were taken into consideration along with disease characteristics. Assessment of PA, however, was only documented by self-report and not objectively measured. 
Table 3 Investigations of structure and function of heart and / or arteries in children and adolescents with JIA with no clinical signs of cardiovascular dysfunction

\begin{tabular}{|c|c|c|c|c|c|c|c|}
\hline Ref. & Design & $\begin{array}{l}\text { No. of patients } \\
\text { and controls }\end{array}$ & Age-group & $\begin{array}{l}\text { Numbers of patients } \\
\text { and subtypes }\end{array}$ & $\begin{array}{l}\text { Number of patients in } \\
\text { treatment at time of } \\
\text { investigation }\end{array}$ & Study parameters & Significant findings \\
\hline \multirow[t]{3}{*}{$\begin{array}{l}\text { Stamato et al. } \\
1995 \text { [78] }\end{array}$} & Descriptive cross-sectional & 36 & $10-17.5$ & $\begin{array}{l}36 \text { HLA-B27 pos. with } \\
\text { spondylarthropathy }\end{array}$ & No information & $\begin{array}{l}\text { Echocardiographic assessment } \\
\text { of left ventricle and the } \\
\text { outflow tract. }\end{array}$ & $\begin{array}{l}\text { Mild aortal regurgitation in patients } \\
\text { unrelated to disease duration }\end{array}$ \\
\hline & \multirow{2}{*}{$\begin{array}{l}\text { with an age matched } \\
\text { healthy control group }\end{array}$} & \multirow[t]{2}{*}{$33^{*}$} & \multirow[t]{2}{*}{$6-18 *$} & & & Atrio-ventricular conduction & \\
\hline & & & & & & Disease duration & \\
\hline \multirow[t]{4}{*}{$\begin{array}{l}\text { Huppertz et al. } \\
2000[79]\end{array}$} & Descriptive cross- sectional & 40 & $6-26$ & 35 HLA-B27 pos ERA & No information & $\begin{array}{l}\text { Echocardiographic } \\
\text { assessment of the left } \\
\text { ventricle functions } \\
\text { before and after exercise. }\end{array}$ & $\begin{array}{l}\text { HLA-B27 positive ERA possibly at risk } \\
\text { for development of aortic regurgitation } \\
\text { and impaired myocardial relaxation }\end{array}$ \\
\hline & \multirow{3}{*}{$\begin{array}{l}\text { with a control group of age } \\
\text { and sexmatched HLA-B27 } \\
\text { neg JIA and } 25 \text { healthy } \\
\text { children }\end{array}$} & \multirow[t]{3}{*}{$15+25^{*}$} & \multirow[t]{3}{*}{$6-25^{*}$} & 3 oligo & & \multirow{3}{*}{$\begin{array}{l}\text { Atrio-ventricular conduction } \\
\mathrm{BP}\end{array}$} & \\
\hline & & & & $1 \mathrm{sJlA}$ & & & \\
\hline & & & & 1 unclassified & & & \\
\hline \multirow[t]{3}{*}{$\begin{array}{l}\text { Oguz et al. } \\
2000 \text { [80] }\end{array}$} & Descriptive cross- sectional. & 30 & $3-15$ & 19 oligo & Mainly NSAID & $\begin{array}{l}\text { Echocardiographic } \\
\text { assessment of the left } \\
\text { ventricle function }\end{array}$ & $\begin{array}{l}\text { Higher systolic and diastolic BP, but } \\
\text { within normal limits, and diastolic } \\
\text { dysfunction of abnormal relaxation }\end{array}$ \\
\hline & \multirow[t]{2}{*}{$\begin{array}{l}\text { with an age matched } \\
\text { healthy control group }\end{array}$} & \multirow[t]{2}{*}{$30^{*}$} & & 10 poly & $\begin{array}{l}\text { The patient with systemic } \\
\text { JIA received corticosteroid }\end{array}$ & \multirow[t]{2}{*}{$\mathrm{BP}$} & type in patients \\
\hline & & & & $1 \mathrm{sJlA}$. & $\begin{array}{l}\text { One unspecified patient } \\
\text { received MTX }\end{array}$ & & \\
\hline \multirow[t]{4}{*}{$\begin{array}{l}\text { Argyropoulou } \\
\text { et al. } 2003 \text { [81] }\end{array}$} & Descriptive cross-sectional & 31 & No data & 18 oligo & No information & $\begin{array}{l}\text { Evaluation by MR of aortic } \\
\text { distensibility and PWV }\end{array}$ & $\begin{array}{l}\text { Lower distensibility and higher PWV in } \\
\text { patients unrelated to JIA subtype }\end{array}$ \\
\hline & \multirow{3}{*}{$\begin{array}{l}\text { with an age matched } \\
\text { healthy control group }\end{array}$} & \multirow[t]{3}{*}{$28^{*}$} & & \multirow[t]{2}{*}{6 poly } & & Disease activity & \multirow{3}{*}{$\begin{array}{l}\text { No correlations between aortic } \\
\text { distensibility / PW } \text { and metabolic and } \\
\text { disease activity parameters }\end{array}$} \\
\hline & & & & & & Insulin sensitivity & \\
\hline & & & & $7 \mathrm{sJlA}$ & & Lipid profile & \\
\hline \multirow[t]{4}{*}{$\begin{array}{l}\text { Bharti et al. } \\
2004 \text { [82] }\end{array}$} & Descriptive cross-sectional. & 35 & No data & oligo & All received NSAID & $\begin{array}{l}\text { Eccocardiographic evaluation } \\
\text { of left ventricular function }\end{array}$ & $\begin{array}{l}\text { Higher systolic and diastolic BP, but } \\
\text { within normal rate, and higher resting } \\
\text { heart rate in patients. }\end{array}$ \\
\hline & \multirow{3}{*}{$\begin{array}{l}\text { with an age matched } \\
\text { healthy control group }\end{array}$} & \multirow[t]{3}{*}{$35^{*}$} & & poly & & & \multirow{3}{*}{$\begin{array}{l}\text { Diastolic dysfunction and higher } \\
\text { systolic and diastolic dimensions and } \\
\text { volumes. }\end{array}$} \\
\hline & & & & sJlA & & & \\
\hline & & & & No numbers given & & & \\
\hline \multirow[t]{5}{*}{$\begin{array}{l}\text { Pietrewicz et al. } \\
2007 \text { [83] }\end{array}$} & \multirow[t]{2}{*}{ Descriptive cross-sectional } & \multirow[t]{2}{*}{40} & \multirow[t]{2}{*}{$4-16$} & \multirow[t]{2}{*}{32 oligo } & \multirow[t]{5}{*}{ No information } & $\begin{array}{l}\text { Echocardiographic } \\
\text { assessment of CIMT }\end{array}$ & \multirow{3}{*}{$\begin{array}{l}\text { Increased cIMT in patients with JIA, } \\
\text { highest in children with polyarthritis, } \\
\text { and correlation between homocystein } \\
\text { and cIMT }\end{array}$} \\
\hline & & & & & & Homocysteine & \\
\hline & \multirow{3}{*}{$\begin{array}{l}\text { with an age matched control } \\
\text { group of healthy children }\end{array}$} & \multirow[t]{3}{*}{$23^{*}$} & \multirow[t]{3}{*}{$3-17^{*}$} & \multirow[t]{3}{*}{8 poly } & & CRP & \\
\hline & & & & & & Lipid profile & Correlation between disease duration \\
\hline & & & & & & Disease duration & \\
\hline
\end{tabular}


Table 3 Investigations of structure and function of heart and / or arteries in children and adolescents with JIA with no clinical signs of cardiovascular dysfunction (Continued)

\begin{tabular}{|c|c|c|c|c|c|c|c|}
\hline Ref. & Design & $\begin{array}{l}\text { No. of patients } \\
\text { and controls }\end{array}$ & Age-group & $\begin{array}{l}\text { Numbers of patients } \\
\text { and subtypes }\end{array}$ & $\begin{array}{l}\text { Number of patients in } \\
\text { treatment at time of } \\
\text { investigation }\end{array}$ & Study parameters & Significant findings \\
\hline \multirow[t]{10}{*}{$\begin{array}{l}\text { Vlahos et al. } \\
2011[84]\end{array}$} & Descriptive cross-sectional & 30 & \multirow[t]{10}{*}{$7-18$} & 15 oligo & 3 NSAID & $\begin{array}{l}\text { Echocardiographic } \\
\text { assessment of cIMT }\end{array}$ & \multirow{3}{*}{$\begin{array}{l}\text { Reduced FMD in patients (as a group) } \\
\text { associated with ESR but without any } \\
\text { association to medication or clinical } \\
\text { disease activity }\end{array}$} \\
\hline & \multirow{9}{*}{$\begin{array}{l}\text { with a BMI, sex, and age } \\
\text { matched control group of } \\
\text { healthy children }\end{array}$} & \multirow[t]{9}{*}{$33^{*}$} & & \multirow[t]{2}{*}{8 poly } & \multirow[t]{2}{*}{4 corticosteroid } & PWV & \\
\hline & & & & & & FMD & \\
\hline & & & & \multirow[t]{7}{*}{$7 \mathrm{sJlA}$} & 15 MTX & Arterial compliance & \multirow{5}{*}{$\begin{array}{l}\text { Increased cIMT in sJIA compared to } \\
\text { controls or non-systemic JIA and } \\
\text { related to use of corticosteroids, } \\
\text { disease activity, BMI, blood pressure, } \\
\text { dyslipidaemia, and age }\end{array}$} \\
\hline & & & & & \multirow[t]{6}{*}{9 TNF-inhibitor } & Disease activity & \\
\hline & & & & & & BMl & \\
\hline & & & & & & $\mathrm{BP}$ & \\
\hline & & & & & & Glucose & \\
\hline & & & & & & Lipid profile & \multirow{2}{*}{$\begin{array}{l}\text { No difference in PWV or arterial } \\
\text { compliance between groups }\end{array}$} \\
\hline & & & & & & Smoking & \\
\hline \multirow[t]{6}{*}{$\begin{array}{l}\text { Koca et al. } \\
2012[85]\end{array}$} & \multirow[t]{4}{*}{ Descriptive cross-sectional } & \multirow[t]{4}{*}{50} & \multirow[t]{6}{*}{$5-16$} & 22 oligo & \multirow[t]{6}{*}{ No information } & $\begin{array}{l}\text { Echocardiographic } \\
\text { assessment of left } \\
\text { ventricle function }\end{array}$ & Impaired diastolic function in patients \\
\hline & & & & 13 poly & & Electrographic & No arrhythmias \\
\hline & & & & 6 ERA & & asse & \\
\hline & & & & 4 PsA & & & \\
\hline & $\begin{array}{l}\text { with a sex, and age matched } \\
\text { control group of healthy } \\
\text { children }\end{array}$ & $70^{*}$ & & $5 \mathrm{sJlA}$ & & & \\
\hline & Follow-up after 12 month. & & & & & & \\
\hline \multirow{5}{*}{$\begin{array}{l}\text { Abul et al. } \\
2012[86]\end{array}$} & \multirow[t]{3}{*}{ Descriptive cross-sectional } & \multirow[t]{3}{*}{55} & \multirow[t]{3}{*}{12.57 SD 2.9} & 24 oligo & 22 NSAID & \multirow{3}{*}{$\begin{array}{l}\text { Echocardiographic } \\
\text { assessment of right } \\
\text { ventricular function }\end{array}$} & \multirow{3}{*}{$\begin{array}{l}\text { Systolic and diastolic dysfunction of } \\
\text { the right ventricle }\end{array}$} \\
\hline & & & & 8 poly & 31 Salazopyrin & & \\
\hline & & & & 15 ERA & $31 \mathrm{MTX}$ & & \\
\hline & \multirow{2}{*}{$\begin{array}{l}\text { with a BMI, sex, and age } \\
\text { matched control group of } \\
\text { healthy children }\end{array}$} & \multirow[t]{2}{*}{$33^{*}$} & \multirow[t]{2}{*}{11.9 SD $2.7^{*}$} & 1 PsA & 25 Corticosteroid & \multirow[t]{2}{*}{ Disease activity } & \multirow{2}{*}{$\begin{array}{l}\text { No association to medication including } \\
\text { steroids and no associations to disease } \\
\text { activity }\end{array}$} \\
\hline & & & & $7 \mathrm{sJlA}$ & 2 TNF-inhibitor & & \\
\hline
\end{tabular}


Table 3 Investigations of structure and function of heart and / or arteries in children and adolescents with JIA with no clinical signs of cardiovascular dysfunction (Continued)

\begin{tabular}{|c|c|c|c|c|c|c|c|}
\hline Ref. & Design & $\begin{array}{l}\text { No. of patients } \\
\text { and controls }\end{array}$ & Age-group & $\begin{array}{l}\text { Numbers of patients } \\
\text { and subtypes }\end{array}$ & $\begin{array}{l}\text { Number of patients in } \\
\text { treatment at time of } \\
\text { investigation }\end{array}$ & Study parameters & Significant findings \\
\hline \multirow{7}{*}{$\begin{array}{l}\text { Alkady et al. } \\
2012 \text { [66] }\end{array}$} & \multirow[t]{3}{*}{ Descriptive cross- sectional } & \multirow[t]{3}{*}{45} & \multirow[t]{7}{*}{$5-16$} & 5 oligo & NSAID & \multirow{3}{*}{$\begin{array}{l}\text { Echocardiographic } \\
\text { assessment of systolic } \\
\text { and diastolic function } \\
\text { (36 patients) }\end{array}$} & \multirow{6}{*}{$\begin{array}{l}\text { Higher resting heart rate and higher } \\
\text { systolic and diastolic BP in patients but } \\
\text { within normal range. Also enlarged left } \\
\text { ventricular systolic dimensions and } \\
\text { diastolic dysfunction. In } 6 \text { patients was } \\
\text { found thickened pericardium, and in } 9 \\
\text { mitral valve thickening and mild } \\
\text { dysfunction.No association with } \\
\text { disease activity reported. }\end{array}$} \\
\hline & & & & 10 poly & 26 MTX & & \\
\hline & & & & 20 ERA & 8 Corticosteroid & & \\
\hline & \multirow{4}{*}{$\begin{array}{l}\text { with a sex and age matched } \\
\text { control group of healthy } \\
\text { children }\end{array}$} & \multirow[t]{4}{*}{$30^{*}$} & & 1 PsA & & \multirow{2}{*}{$\begin{array}{l}\text { Spirometry and CO } \\
\text { diffusion ( } 30 \text { patients) }\end{array}$} & \\
\hline & & & & $9 \mathrm{sJlA}$ & & & \\
\hline & & & & & & $\begin{array}{l}23 \text { patients and controls } \\
\text { had both investigations }\end{array}$ & \\
\hline & & & & & & Disease activity and duration & $\begin{array}{l}\text { In } 19 \text { out of } 30 \text { patients was found a } \\
\text { reduction in pulmonary function } \\
\text { primarily of a restrictive pattern, } \\
\text { inversely correlated to disease duration } \\
\text { and severity / treatment with MTX }\end{array}$ \\
\hline \multirow{7}{*}{$\begin{array}{l}\text { Breda et al. } \\
2012 \text { and } \\
2013[33,34]\end{array}$} & \multirow{3}{*}{$\begin{array}{l}\text { Longitudinal intervention } \\
\text { study of } 12 \text { months }\end{array}$} & \multirow[t]{3}{*}{38} & \multirow[t]{3}{*}{$4.7-9.4$} & Oligo- or poly & NSAID & CIMT & \multirow{7}{*}{$\begin{array}{l}\text { Improvement in all baseline disease } \\
\text { parameters, including BT, after one year of } \\
\text { " treatment to target" except CHDL that } \\
\text { was found normal at baseline and did not } \\
\text { change. Positive correlation between cIMT } \\
\text { and LDL and IL-1 beta, no correlation to } \\
\text { CRP or ESR.BT was found elevated at } \\
\text { baseline but within normal range }\end{array}$} \\
\hline & & & & Mild disease in 22 & MTX at baseline. & Clinical disease activity & \\
\hline & & & & & & ESR, CRP & \\
\hline & \multirow{4}{*}{$\begin{array}{l}\text { with a sex, age and puberty } \\
\text { stage matched control group } \\
\text { of healthy children }\end{array}$} & \multirow[t]{4}{*}{$40^{*}$} & \multirow[t]{4}{*}{$4.1-8.6^{*}$} & \multirow{4}{*}{$\begin{array}{l}\text { Aggressive disease } \\
\text { in } 16 \text { with poly }\end{array}$} & \multirow{3}{*}{$\begin{array}{l}\text { During follow-up disease } \\
\text { control was obtained by } \\
22 \text { in treatment with } \\
\text { NSAID +/- conventional } \\
\text { DMARDs }\end{array}$} & $\begin{array}{l}\text { Proinflammatory cytokines } \\
\text { BP } \\
\text { Lipid profile } \\
\text { Oxidant status }\end{array}$ & \\
\hline & & & & & & \multirow{2}{*}{$\begin{array}{l}\text { BP } \\
\text { Lipid profile } \\
\text { Oxidant status }\end{array}$} & \\
\hline & & & & & & & \\
\hline & & & & & $\begin{array}{l}16 \text { patients needed more } \\
\text { aggressive treatment with } \\
\text { TNF-alfa inhibition }\end{array}$ & Oxidant status & \\
\hline \multirow{10}{*}{$\begin{array}{l}\text { Glowinska- } \\
\text { Olszewska } \\
\text { et al. } 2013 \text { [32] }\end{array}$} & \multirow[t]{9}{*}{ Descriptive cross- sectional } & \multirow[t]{9}{*}{58} & \multirow[t]{9}{*}{$11-15$} & 28 oligo & 42 Corticosteroid & BMI & \multirow{3}{*}{$\begin{array}{l}22 \% \text { of the patients met the criteria for } \\
\text { overweight or obesity. }\end{array}$} \\
\hline & & & & 26 poly & $28 \mathrm{MTX}$ & FMD & \\
\hline & & & & $4 \mathrm{sJlA}$ & 14 Biologics & CIMT & \\
\hline & & & & Clin. active & 9 Unspec. DMARDS & LVMi & Lower FMD and higher cIMT, LVMi, BMI, \\
\hline & & & & & & Disease activity & $\begin{array}{l}\text { and BP in patients as a group compared } \\
\text { to controls; highest CIMT and lowest }\end{array}$ \\
\hline & & & & & & BP & FMD in obese patients. No difference \\
\hline & & & & & & CRP & and inactive disease and no difference \\
\hline & & & & & & IL-6, TNF-alfa & between JIA subtypes. \\
\hline & & & & & & Lipid profile & \\
\hline & $\begin{array}{l}\text { with a sex and age } \\
\text { matched control group }\end{array}$ & $36^{*}$ & $12-15^{*}$ & $\begin{array}{l}\text { Clin. inactive } \\
\text { inflammation: } 28\end{array}$ & & Insulin sensitivity & \\
\hline
\end{tabular}


Table 3 Investigations of structure and function of heart and / or arteries in children and adolescents with JIA with no clinical signs of cardiovascular dysfunction (Continued)

\begin{tabular}{|c|c|c|c|c|c|c|c|}
\hline$\overline{\text { Ref. }}$ & Design & $\begin{array}{l}\text { No. of patients } \\
\text { and controls }\end{array}$ & Age-group & $\begin{array}{l}\text { Numbers of patients } \\
\text { and subtypes }\end{array}$ & $\begin{array}{l}\text { Number of patients in } \\
\text { treatment at time of } \\
\text { investigation }\end{array}$ & Study parameters & Significant findings \\
\hline \multirow{8}{*}{$\begin{array}{l}\text { Raab et al. } \\
2013 \text { [36] }\end{array}$} & \multirow{7}{*}{$\begin{array}{l}\text { Descriptive cross- sectional } \\
\text { study of young adults with } \\
\text { severe JIA, based on } \\
\text { self-reports }\end{array}$} & \multirow[t]{7}{*}{344} & \multirow[t]{7}{*}{19.7 SD 2.8} & 28 oligo & \multirow[t]{3}{*}{215 Biologics } & \multirow[t]{3}{*}{ Comorbidity } & \multirow{4}{*}{$\begin{array}{l}\text { In } 9.9 \% \text { were reported CVD with } \\
\text { hypertension in } 7.3 \% \text {, not different from } \\
\text { the control group }\end{array}$} \\
\hline & & & & 50 extended oligo & & & \\
\hline & & & & 91 RFneg poly & & & \\
\hline & & & & 37 RFpos poly & 151 MTX & Disease activity & \\
\hline & & & & 75 ERA & 64 Other conventional & Health & \multirow{3}{*}{$\begin{array}{l}\text { CVD, mainly hypertension, was } \\
\text { reported in } 40.6 \% \text { of } 15 \text { patients with } \\
\text { sJlA }\end{array}$} \\
\hline & & & & 37 PsA & \multirow[t]{2}{*}{ DMARDs } & \multirow[t]{2}{*}{ Functional deficits, } & \\
\hline & & & & $15 \mathrm{~s} / \mathrm{A}$ & & & \\
\hline & $\begin{array}{l}\text { and compared to an age } \\
\text { and sex matched cohort } \\
\text { sampled from the general } \\
\text { population }\end{array}$ & $688^{*}$ & & 11 other arthritis & & & \\
\hline \multirow{10}{*}{$\begin{array}{l}\text { Aulie et al. } \\
2014 \text { [37] }\end{array}$} & \multirow{9}{*}{$\begin{array}{l}\text { Cross-sectional, observational } \\
\text { study of patients with } \\
\text { disease duration of more } \\
\text { than } 23 \text { years }\end{array}$} & \multirow[t]{9}{*}{87} & \multirow[t]{9}{*}{$34.8-40.6$} & 15 oligo & 25 TNF-inhibitor & $\mathrm{BP}$ & \multirow{4}{*}{$\begin{array}{l}\text { Higher systolic and diastolic BT and } \\
\text { small elevation of PWV in patients } \\
\text { related to diastolic BT }\end{array}$} \\
\hline & & & & 14 extended oligo & 19 Methotrexate & PWV & \\
\hline & & & & 13 RF neg poly & 23 Daily NSAID & Alx & \\
\hline & & & & 5 RF pos poly & \multirow[t]{6}{*}{6 Prednisolone } & Coronary calcification & \\
\hline & & & & 18 ERA & & Disease activity & \multirow{5}{*}{$\begin{array}{l}\text { No difference in Alx between patients } \\
\text { and controls, but a positive association } \\
\text { to diastolic BP, accumulated disease } \\
\text { parameters inclusive treatment with } \\
\text { prednisolone, and daily smoking, and a } \\
\text { negative association to vigorous physical } \\
\text { activity }\end{array}$} \\
\hline & & & & 15 PsA & & CRP, ESR & \\
\hline & & & & & & $\mathrm{BMI}$ and waist circumference & \\
\hline & & & & $4 \mathrm{sJlA}$ & & Lipid profile & \\
\hline & & & & 3 unclassified & & Insulin resistance & \\
\hline & $\begin{array}{l}\text { With an age and sex matched } \\
\text { group without DM or } \\
\text { inflammatory arthritis selected } \\
\text { from a national population } \\
\text { register }\end{array}$ & $87^{*}$ & & & & $\begin{array}{l}\text { Self reported habits of } \\
\text { smoking and physical } \\
\text { activity }\end{array}$ & $\begin{array}{l}\text { Coronary calcification was present in } \\
26 \% \text { of patients, a frequency not } \\
\text { different from that found in a large } \\
\text { population study, and related to waist } \\
\text { circumference, BMI, systolic BP, blood } \\
\text { glucose and years on daily prednisolone }\end{array}$ \\
\hline \multirow[t]{4}{*}{$\begin{array}{l}\text { Lianza et al. } \\
2014 \text { [77] }\end{array}$} & $\begin{array}{l}\text { Two year prospective } \\
\text { observational study }\end{array}$ & 21 & $2.2-17.8$ & 21 poly & TNF-inhibitor & $\begin{array}{l}\text { Systolic and diastolic cardiac } \\
\text { function evaluated by } \\
\text { echocardiography }\end{array}$ & \multirow{2}{*}{$\begin{array}{l}\text { Mild ventricular diastolic dysfunction in } \\
\text { JA with no relation to NT-pro-BNP. } \\
\text { Possible association between NT-pro- } \\
\text { BNP and disease activity. }\end{array}$} \\
\hline & \multirow[t]{3}{*}{$\begin{array}{l}\text { with age and sex matched } \\
\text { healthy controls }\end{array}$} & \multirow[t]{3}{*}{$22^{*}$} & \multirow[t]{3}{*}{$6-17^{*}$} & & & $\begin{array}{l}\text { Cardiac biomarkers: } \\
\text { NT-pro-BNP }\end{array}$ & \\
\hline & & & & & & Troponin T & \multirow{2}{*}{$\begin{array}{l}\text { No sign of cardiovascular deterioration } \\
\text { during treatment with TNF-alfa inhibitor. }\end{array}$} \\
\hline & & & & & & Disease activity & \\
\hline
\end{tabular}

With an age and sex matched 87

national population

Two year prospective

with age and sex matched

Disease activity 
Table 3 Investigations of structure and function of heart and / or arteries in children and adolescents with JIA with no clinical signs of cardiovascular dysfunction (Continued)

\begin{tabular}{|c|c|c|c|c|c|c|c|}
\hline Ref. & Design & $\begin{array}{l}\text { No. of patients } \\
\text { and controls }\end{array}$ & Age-group & $\begin{array}{l}\text { Numbers of patients } \\
\text { and subtypes }\end{array}$ & $\begin{array}{l}\text { Number of patients in } \\
\text { treatment at time of } \\
\text { investigation }\end{array}$ & Study parameters & Significant findings \\
\hline \multirow{7}{*}{$\begin{array}{l}\text { Satija et al. } \\
2014 \text { [71] }\end{array}$} & \multirow{6}{*}{$\begin{array}{l}\text { Cross sectional, } \\
\text { observational }\end{array}$} & 31 & \multirow[t]{7}{*}{$3.5-16$} & 2 oligo & \multirow[t]{7}{*}{ No DMARD or biologics } & cIMT, & \multirow{6}{*}{$\begin{array}{l}\text { Reduced arterial elasticity in patients } \\
\text { indicative of increased stiffness, all had } \\
\text { normal BT. No difference in cIMT, FMD, } \\
\text { GTN-MD between subgroups and } \\
\text { controls }\end{array}$} \\
\hline & & $31^{*}$ & & \multirow[t]{3}{*}{2 RF neg poly } & & Arterial elasticityFMD & \\
\hline & & & & & & GTN-MD & \\
\hline & & & & & & BT & \\
\hline & & & & 4 RF pos poly & & Disease activity & \\
\hline & & & & 9 ERA & & ESR & \\
\hline & $\begin{array}{l}\text { With an age and sex } \\
\text { matched control group } \\
\text { of healthy children }\end{array}$ & & & 14 sJlA & & Lipid-profile & Correlation between cIMT and ESR \\
\hline
\end{tabular}

SD is given in brackets. Aix Augmentation index, alMT aorta intima-media thickness, BP blood pressure, CAC, coronary artery calcification, cIMT, carotis intima-media thickness, ERA Entesitis-related arthritis, ESR erythrocyte sedimentation rate, FMD flow mediated dilatation, GTN-MD glyceryl trinitrate mediated dilatation, LVMi left ventricle mass index, MTX Methotrexate, NSAID Non Steroid Anti-Inflammatory Drug, Oligo oligoarticular JIA, RF Rheuma-factor, Poly Polyarticular JIA, PsA Psoriasis associated JIA, SJIA systemic JIA, DMARD disease modifying anti-rheumatic drugs, PWV pulse wave velocity 


\section{Risk factors for premature subclinical atherosclerosis in JIA}

The studies included in this review use various techniques for the assessment of cardiovascular function and, except for the studies of young adults with JIA, include relatively small groups of children or adolescents with variable subtypes of JIA in diverse states of activity and on different medications. These different circumstances make meta- and subgroup-analyses difficult. Nevertheless, taken together we find it reasonable to conclude that surrogate markers of early atherosclerosis are present more often in JIA patients than in their healthy peers. Several studies, including those of young adults with JIA, show a significantly higher rate of elevated blood pressure, ventricular dysfunction and increased cIMT as a general feature of JIA, possibly associated with more pronounced systemic inflammation and dyslipidemia. Also the signs of aortitis and myocarditis, seen most prominently in patients with ERA (Enthesitis-related arthritis), support the concept of persistent systemic inflammation as an important driver of premature cardiovascular disease.

Longer term follow-up studies, however, have not shown any increase in clinically overt atherosclerotic events in young adult (less than 41 years of age) with long-standing JIA, which points to a slowly-developing, multifaceted process which may be amenable to preventive measures.

Elevated blood pressure, prehypertension as seen in several of the studies, is associated with increased cIMT and Left Ventricle Mass Index (LVMi), diastolic dysfunction and arterial stiffness, independently of BMI but associated with dyslipidemia [38, 39]. Dyslipidemia may be a feature of persistent inflammation [40-42] and may be associated with Metabolic Syndrome (MetS), a cluster of independent risk factors for atherosclerosis [43] that are also associated with persistent inflammation [44]. The occurrence of MetS in JIA has not yet been studied in great detail (for a recent review see Zanette et al. [45]). Glucocorticoid treatment may lead to insulin resistance [46-49], which is a hallmark of MetS. Since the introduction of MTX and specific biological inhibitors of inflammation, glucocorticoids are typically used in lower dosages and for shorter periods of time, but may still be a concern regarding metabolic dysfunction, risk of hypertension and premature atherosclerosis as seen in the studies by Raab et al. [36] and Aulie et al. [37]. In European studies from 1969 and 1977, secondary amyloidosis, with risk of hypertension due to kidney deposition, was reported to occur in 5-7 \% of JIA patients, most often in children with systemic JIA. In a retrospective hospital-based study in Turkey [50] looking at 196 children with JIA from 1995 to 2004, only three patients (1.4 \%) developed amyloidosis a frequency comparable to that reported by Raab et al. [36]. Interestingly, information on secondary amyloidosis in children with JIA has only appeared in scattered case reports in the last few years; presumably the prevalence of secondary amyloidosis is declining, as more efficient anti-inflammatory medications have become available.

By addressing chronic inflammation aggressively, the impact of the known risk factors for premature development of atherosclerosis (i.e. hypertension, dyslipidemia, and insulin resistance), may well diminish in parallel with the decreasing inflammation; preventable risk factors (including overweight, physical inactivity, and tobacco smoking) should then be considered.

High BMI (overweight and obesity) is by itself, associated with low grade systemic inflammation [51-55]. As elevated BMI could, thus, potentially amplify a preexisting inflammatory condition and thereby enhance the risk of premature atherosclerosis, a number of studies have looked at overweight and obesity in patients with JIA. In a recent cross-sectional study of 154 American children and adolescents with JIA, $18 \%$ met criteria for obesity and an additional $12 \%$ were overweight, similarly to what is seen in otherwise healthy American children [56]. The authors did not find an association between obesity and clinical disease activity, duration of illness or medication; markers of inflammation (CRP and ESR) did not correlate with BMI. Statistical power was, however, limited in this relatively small study which did not include healthy controls. Two other small recent crosssectional studies of children and adolescents with JIA, in Morocco [57] and Poland [32], found higher rates of obesity and overweight than reported in the national references. In the study from Poland obese patients had higher levels of inflammatory markers in the blood, dyslipidemia and signs of insulin resistance as well as higher blood pressure compared to normal weight patients, but there were no obese healthy children in the control group. A controlled cross-sectional study from Brazil, looking at body composition in 42 female children and adolescents with JIA, showed increased body fat and truncal fat in prepubertal children with JIA, independent of subtype and medication [58]; this finding is of interest since abdominal fat is considered the origin of systemic inflammation associated with obesity. Weight gain and increase in visceral fat have been described in patients with RA receiving TNF- $\alpha$ - and IL-6-inhibitors, but weight gain was not found in a cohort of children with JIA on TNF- $\alpha$ inhibitor therapy compared with JIA patients not treated with TNF- $\alpha$ inhibitors [59]; body composition was, however, not assessed.

Physical inactivity is another modifiable risk factor for premature atherosclerosis [16-21]. More specifically, a study on adolescents and young adults by Edwards et al. [18] showed that higher PA was an independent 
predictor for lower arterial stiffness, measured as peripheral arterial distensibility and AIx.

In children with JIA, a sedentary lifestyle due to pain, fatigue and sleep disturbances is not uncommon [60]. Lelieveld et al. [61] found low fitness and low levels of PA in adolescents with JIA compared to healthy children. The inactive lifestyle was, however, unrelated to the degree of disease activity, and remission of clinical symptoms did not result in a more active lifestyle, which signifies complex reasons for physical inactivity in these patients. Also a recent study [62] reported reduced PA unrelated to pain or objective signs of inflammation in children and adolescents with JIA. Unfortunately PA was only assessed in one of the investigations on subclinical atherosclerosis in JIA [37] and in that study only by selfreports, a less reliable means of assessment.

A cross-sectional study of fitness in children with JIA showed significantly lower aerobic capacity among children aged 6 to 11 years with polyarticular JIA compared with matched healthy controls [63]. This finding was supported by a subsequent meta-analysis of 5 studies with a total of 144 children [64] and a more recent study [65], in which the investigators found a significant negative correlation between disease activity and aerobic capacity in children, adolescents and young adults across all JIA subtypes. Also patients in remission were found to have reduced aerobic capacity. Details regarding PA are not given, but the authors state that the lower aerobic capacity was not simply explained by sedentary lifestyle, and the authors speculate that muscle wasting, lung dysfunction, as also found by Alkady et al. [66], and anemia due to chronic inflammation may be important contributing factors. In healthy children, Dencker et al. [67] also found only a weak association between PA and aerobic fitness. This could be due to assessment methods, as intervention studies show increased aerobic fitness connected with increased PA [17]. Muscle wasting, lung dysfunction, and anemia due to chronic inflammation should diminish in the wake of more effective disease control, thus making regular PA possible for patients with JIA.

Finally, tobacco smoking is still a common and important risk factor for development of cardiovascular disease in teenagers and young adults [68]. In a questionnaire study of US adolescents with JIA, as many as $15.4 \%$ reported use of tobacco in the last year [69]. A cross-sectional survey from Switzerland, of 7253 adolescents aged 16 to 20 years, adolescents with a chronic condition, defined as a disability or a disease lasting $>6$ months and requiring continuous medical care, reported significantly higher rates of risk behavior including tobacco smoking than in a comparison group of healthy adolescents [70]. The investigation by Aulie et al. [37] likewise reported a significantly higher rate of daily smoking in the patients than in controls.

\section{Conclusions}

In this review of the current literature we find convincing evidence for the existence of subclinical signs of premature atherosclerosis in patients with JIA, but the studies available do not provide a clear picture as to the cause. Inflammation is probably a driver, but attention must also be paid to other known risk factors for development of atherosclerosis, including obesity, physical inactivity and tobacco smoking - risk factors which are open to modification by changes in lifestyle.

With the advent of increasingly effective drugs for treating chronic inflammatory diseases in childhood and adolescence, and the resulting reduced risk of concomitant functional impairment, we should now broaden our strategy of management and address other potential consequences of chronic disease.

Reestablishment of a healthy lifestyle, including avoidance of adipositas and physical inactivity, is of great importance for gaining the full benefit of effective antiinflammatory treatment and in securing a healthy life in adulthood.

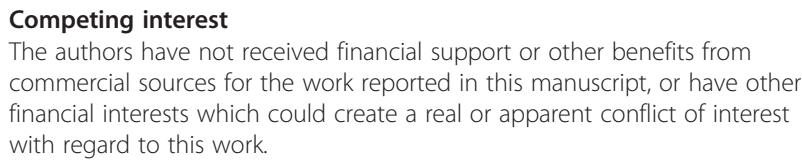
commercial sources for the work reported in this manuscript, or have other financial interests which could create a real or apparent conflict of interest with regard to this work.

\section{Authors' contributions}

All authors contributed to the final manuscript, $A B$ drafted and rewrote the manuscript after revisions. All authors read and approved the final manuscript. $A B$ is a research fellow at Department of Paediatrics and Adolescent Medicine, Rigshospitalet, Denmark. RF is consultant at Children's Hospital Boston, USA. FKP is consultant at Department of Paediatrics and Adolescent Medicine, Rigshospitalet, Denmark. SdF is consultant at Children's Hospital Boston, USA. KM is professor and consultant at Department of Paediatrics and Adolescent Medicine, Rigshospitalet, Denmark. FKP is consultant at Department of Paediatrics and Adolescent Medicine, Rigshospitalet, Denmark.

\section{Acknowledgements}

$A B$ is funded by a scholarship from TRYG foundation.

\section{Author details}

${ }^{1}$ Department of Paediatrics and Adolescent Medicine, JMC Research Unit, Rigshospitalet Afs. 7821, Tagensvej 22, DK 2200 Copenhagen N, Denmark. ${ }^{2}$ Children's Hospital Boston, Boston, USA. ${ }^{3}$ Department of Paediatrics and Adolescent Medicine, Rigshospitalet, Copenhagen, Denmark. ${ }^{4}$ Department of Paediatrics and Adolescent Medicine, and Institute for Inflammation Research, Rigshospitalet, Copenhagen, Denmark.

Received: 8 October 2015 Accepted: 18 December 2015 Published online: 06 January 2016

\section{References}

1. Prakken B, Albani S, Martini A. Juvenile idiopathic arthritis. Lancet. 2011; 377(9783):2138-49.

2. Minden K. Adult outcomes of patients with juvenile idiopathic arthritis. Horm Res. 2009;72 Suppl 1:20-5. 
3. Nordal E, Zak M, Aalto K, Berntson L, Fasth A, Herlin T, et al. Ongoing disease activity and changing categories in a long-term nordic cohort study of juvenile idiopathic arthritis. Arthritis Rheum. 2011;63(9):2809-18.

4. Selvaag AM, Aulie HA, Lilleby $\vee$, Flatø B. Disease progression into adulthood and predictors of long-term active disease in juvenile idiopathic arthritis. Ann Rheum Dis. 2014;0:1-6.

5. Mahmood SS, Levy D, Vasan RS, Wang TJ. The Framingham Heart Study and the epidemiology of cardiovascular disease: a historical perspective. Review. Lancet 2013, dx.doi.org/10.1016/50140-6736(13)61752-3

6. Magnusson $C G$, Smith KJ, Juonala M. What the long term cohort studies that began in childhood have taught Us about the origins of coronary heart disease. Curr Cardiovasc Risk Rep. 2014;8:373.

7. Laitinen TT, Pahkala K, Magnusson CG, Oikonen M, Viikari JSA, Sabin MA, et al. Lifetime measures of ideal cardiovascular health and their association with subclinical atherosclerosis: the cardiovascular risk in young Finns study. Int J Cardiol. 2015;185:186-91.

8. Avina-Zubieta JA, Thomas J, Sadatsafavi M, Lehman AJ, Lacaille D. Risk of incident cardiovascular events in patients with rheumatoid arthritis: a metaanalysis of observational studies. Ann Rheum Dis. 2012;71:1524-29.

9. Solomon DH, Reed GW, Kremer JM, Curtis JR, Farkouk ME, Harrold LR, et al. Disease activity in rheumatoid arthritis and the risk of cardiovascular events. Arthritis Rheum. 2015;67:1449-55.

10. del Rincón PJF, O'Leary DH, Battafarano DF, Erikson JM, Restrepo JF, et al. Systemic inflammation and cardiovascular risk factors predict rapid progression of atherosclerosis in rheumatoid arthritis. Ann Rheum Dis. 2015; 74:1118-23.

11. Berenson GS, Wendy A, Wattigney MS, Richard ET, William P, Newman III, et al. Athesclerosis of the aorta and coronary arteries and cardiovascular risk factors in persons aged 6 to 30 years and studied at necropsy (the Bogalusa heart study). Am J Cardiol. 1992;70:851-8.

12. Stary HC, Chandler AB, Glagov S, Guyton JR, Insull W, Rosenfeld ME, et al. A definition of initial, fatty streaks, and intermediate lesions of atherosclerosis. A report from the committee on vascular lesions of the council on arteriosclerosis, american heart association. Circulation. 1994;89:2462-78.

13. Wissler RW, Strong JP. the PDAY Research Group. Risk factors and Progression of Athesclerosis in Youth. Am J Pathology. 1998;153(4):1023-33.

14. McGill HC, McMahan CA, Herderick EE, Malcom GT, Tracy RE, Strong JP. Origin of athesclerosis in childhood and adolescence. Am J Clin Nutr. 2000; 72(suppl):1307S-15S.

15. Berenson GS, Srinivasan SR, Bao W, Newman WP, Tracy RE. Wattigney WA for the Bogalusa heart study. Association between multiple cardiovascular risk factors and athesclerosis in children and young adults. N Engl J Med. 1998;338:1650-6.

16. Andersen LB, Harro M, Sardinha LB, Froberg K, Ekelund U, Brage S, et al. Physical activity and clustered cardiovascular risk in children: a crosssectional study (The European Youth Heart Study). Lancet. 2006;22(9532): 299-304. 368.

17. Andersen LB, Riddoch C, Kriemler S, Hills A. Physical activity and cardiovascular risk factors in children. Br J Sports Med. 2011;45:871-6.

18. Edwards NM, Daniels SR, Claytor RP, Khoury PR, Dolan LM, Kimball TR, et al. Physical activity is independently associated with multiple measures of arterial stiffness in adolescents and young adults. Metabolism. 2012;61: 869-72.

19. Ried-Larsen M, Grøntved A, Kristensen PL, Froberg K, Andersen LB. Moderate-and-vigorous physical activity from adolescence to adulthood and subclinical atherosclerosis in adulthood: prospective observations from the European Youth Heart Study. Br J Sports Med. 2013;00:1-7.

20. Lee I, Shiroma EJ, Lobelo F, Puske P, Blair SN, Katzmarzyk PT. For the lancet physical activity series working group. Lancet. 2012;380(9838):219-29.

21. Pahkala K, Laitinen TT, Heinonen OJ, Viikari JSA, Rönnemaa T, Niinikoski H, et al. Association of fitness with vascular intima-media thickness and elasticity in adolescence. Pediatrics. 2013;132:e77-84.

22. Lloyd-Jones DM, Hong Y, Labarthe D, Mozaffarian D, Appel $\sqcup$, Van HL, et al. Defining and setting national goals for cardiovascular health promotion and disease reduction: the American Heart Association's strategic impact goal through 2010 and beyond. Circulation. 2010;121:586-613.

23. Lorenz MW, Marcus HS, Bots ML, Roswall M, Sitzer M. Prediction of clinical cardiovascular events with carotid intima-media thickness a systematic review and meta-analysis. Circulation. 2007;115:459-67.

24. Lorenz MW, Polak JF, Kavousi M, Mathiesen EB, Völzke $H$, Tuomainen $T$, et al. On behalf of the PROG-IMT study group. Carotid intima-media thickness progression to predict cardiovascular events in the general population (the PROG-IMT collaborative project): a meta-analysis of individual participant data. Lancet. 2012;379:2053-62.

25. Krebs A, Schmidt-Trucksäss A, Alt J, Doerfer J, Krebs K, Winkler K, et al. Synergistic effect of elevated systolic blood pressure and hypercholesterolaemia on carotid intima-media thickness in children and adolescents. Pediatr Cardiol. 2009;30:1131-6.

26. Lamotte C, Iliescu C, Libersa C, Gottrand F. Increased intima-media thickness of the carotid artery in childhood: a systematic review of observational studies. Eur J Pediatr. 2011;170:719-29.

27. Li S, Chen W, Srinivasan SR, Bond MG, Tang R, Urbina EM, et al. Childhood cardiovascular risk factors and carotid vascular changes in adulthood: the Bogalusa Heart Study. JAMA. 2003;290(17):2271-6.

28. Raitakari OT, Juonala M, Kähönen M, Taittonen L, Laitinen T, Mäki-Torkko N, et al. Cardiovascular risk factors in childhood and carotid artery intimamedia thickness in adulthood. The cardiovascular risk in young Finns study. JAMA. 2003;290:2277-83.

29. Urbina EM, Williams RV, Alpert BS, Collins RT, Daniels SR, Hayman L, et al. Noninvasive assessment of subclinical athesclerosis in children and adolescents: recommendations for standart assessment for clinical research: a scientific statement from the American heart association. Hypertension. 2009;54(919):50.

30. Canas JA, Sweeten S, Balagopal P. Biomarkers for cardiovascular risk in children. Curr Opin Cardiol Review. 2013;28:103-14.

31. Kozera L, Andrews J, Morgan AW. cardiovascular risk and rheumatoid arthritis - the next step: differentiating true soluble biomarkers of cardiovascular risk from surrogate measures of inflammation. Reumatology. 2011;50:1944-54.

32. Glowinska-Olszewska B, Bossowski A, Dobrenko E, Hryniewicz A, Konstantynowicz J, Milewski R et al. Subclinical Cardiovascular System Changes in Obese Patients with Juvenile Idiopathic Arthritis. Mediaters of Inflammation 2013;2013:436702. doi.org/10.1155/2013/436702

33. Breda L, Di Marzio D, Giannini C, Gaspari S, Nozzi M, Scarinci A et al. Relationship between inflammatory markers, oxidant-antioxidant status and intima-media thickness in prepubertal children with juvenile idiopathic arthritis. Clin. Res. Cardiol 2012;doi 10.1007/s00392-012-0496-3

34. De Sanctis S, Marcovecchio ML, Gaspari S, Del Torto M, Mohn A, Chiarelli F, et al. Etanercept improves lipid profile and oxidative stress measures in patients with juvenile idiopathic arthritis. J Rheumatol. 2013;40(6):943-8.

35. Minden K, Niewerth M, Zink A, Seipelt E, Foeldvari I, Girschick H et al. Longterm outcome of patients with JIA treated with Etanercept, results of the biologic register JuMBO. Rheumatology 2012; doi:10.1093/rheumatology/ kes019

36. Raab A, Sengler C, Niewerth M, Klotsche J, Horneff G, Zink A, et al. Comorbidity profiles among adult patients with juvenile idiopathic arthritis: results of a biologic register. Clin Exp Rheumatol. 2013;31:796-802.

37. Aulie HA, Selvaag AM, Günther A, Lilleby V, Molberg $\varnothing$, Hartmann A et al. Arterial haemodynamics and coronary artery calcification in adult patients with juvenile idiopathic arthritis. Ann Rheum Dis. 2014;0:1-7.doi:10.1136/ annrheumdis-2013-204804

38. Garza-García C, Rocío S, Orea-Tejeda A, Castillio-Martínez L, Eduardo C, López-Campos JL et al. Risk factors for Asymptomatic Ventricular Dysfunction in Reumatoid Arthritis Patients. ISRN Cardiology 2013 ID 635439. Doi.org/10.1155/3013/635439

39. Urbina EM, Khoury PR, McCoy C, Daniels SR, Kimball TR, Dolan LM. Cardiac and vascular consequences of Pre-hypertension in youth. J Clinical Hypertens. 2011;13(5):332-42.

40. Marangoni RG, Hayata AL, Borba EF, Azevedo PM, Bonfa E, Schainberg CG. Decreased high-density lipoprotein cholesterol levels in polyarticular juvenile idiopathic arthritis. Clinics. 2011;66(9):1549-52.

41. Shen C, Yao T, Yeh K, Huang J. Association of disease activity and antirheumatic treatment in juvenile idiopathic arthritis with serum lipid profiles: A prospective study. Semin Arthritis Rheum. 2013;42:590-6.

42. Robertson J, Peters MJ, Mclnnes IB, Sattar N. Changes in lipid levels with inflammation and therapy in RA: a maturing paradigm. Nat Rev Rheumatol. 2013:9:513-23.

43. Alberti KG, Eckel RH, Grundy SM, Zimmet PZ, Cleeman JI, Donato KA, et al. Harmonizing the metabolic syndrome: a joint interim statement of the international diabetes federation task force on epidemiology and prevention; national heart, lung, and blood institute; american heart association; world heart federation; international atherosclerosis society; and 
international association for the study of obesity. Circulation. 2009;120(16): $1640-5$.

44. Crowson CS, Myasoedova E, Davis 3rd JM, Matteson EL, Roger VL, Therneau $\mathrm{TM}$, et al. Increased prevalence of metabolic syndrome associated with rheumatoid arthritis in patients without clinical cardiovascular disease. J Rheumatol. 2011;38(1):29-3.

45. Zanette CA, Machado SH, Brenol JCT, Xavier RM. Metabolic syndrome and juvenile idiopathic arthritis. Bras J Reumatol. 2010;50(2):190-204.

46. Hoes JN, van der Goes MC, van Raalte DH, van der Zijl NJ, den Uyl D, Lems WF, et al. Glucose tolerance, insulin sensitivity and beta-cell function in patients with rheumatoid arthritis treated with or without low-to-medium dose glucocorticoids. Ann Rheum Dis. 2011;70(11):1887-94.

47. Vannucci G, Cantarini L, Giani T, Marrani E, Moretti D, Pagnini I, et al. Glucocorticoids in the management of systemic juvenile idiopathic arthritis. Pediatr Drugs. 2013;15(5):343-9.

48. Bijlsma JWJ, Jacobs JWG. Glucocorticoids in the treatment of rheumatoid arthritis: still used after 65 years. AnnNY AcadSci. 2014;1318:27-31. ISSN 0077-8923.

49. Schiappapietra B, Varnier G, Rosina S, Consolaro A, Martini A, Ravelli A. Glucocorticoids in juvenile idiopathic arthritis. Neuroimmunomodulation. 2015:22:112-18.

50. Yilmaz M, Kendirli SG, Altintas DU, Karakoc GB, Inal A, Kilic M. Juvenile idiopathic arthritis profile in Turkish children. Pediatr Int. 2008;50:154-8.

51. Ogden CL, Carroll MD, Kit BK, Flegal KM. Prevalence of obesity and trends in body mass index among US children and adolescents, 1999-2010. JAMA. 2012;307(5):483-90.

52. Gupta N, Goel K, Shah P, Misra A. Childhood obesity in developing countries: epidemiology, determinants, and prevention. Endocr Rev. 2012; 33(1):48-70.

53. Rondinone CM. Adipocyte-derived hormones, cytokines, and mediators. Endocrine. 2006;29(1):81-90. Evt erstattes af Ouchi 2011.

54. Tam CS, Clement K, Baur LA, Tordjman J. Obesity and low-grade inflammation: a paediatric perspective. Obes reviews : an official J Int Assoc Stud Obes. 2010;11(2):118-26

55. Goebel RJ, Jensen SM, Froekiaer H, Moelgaard C, Michaelsen KF. Obesity, inflammation and metabolic syndrome in Danish adolescents. Acta Paediatr. 2012;101:192-200.

56. Pelajo CF, Lopez-Benitez JM, Miller LC. Obesity and disease activity in juvenile idiopathic arthritis. Pediatr Rheumatol online J. 2012;10(1):3.

57. Amine B, Ibn YY, Rostom S, Hajjaj-Hassouni N. Prevalence of overweight among Moroccan children and adolescents with juvenile idiopathic arthritis. Joint Bone Spine. 2011;78(6):584-6.

58. Caetano MC, Sarni ROS, Terreri MTL, Ortiz TT, Pinheiro M, de Souza FIS, et al. Excess of adiposity in female children and adolescents with juvenile idiopathic arthritis. Clin Rheumatol. 2012;31:967-71.

59. Shafferman A, Fontaine KR, Cron RQ, Beukelman T. Changes in body mass index in children with juvenile idiopathic arthritis treated with tumor necrosis factor inhibitors. J Rheumatol. 2014;41(1):113-8.

60. Butbul AY, Stremler R, Benseler SM, Cameron B, Laxer RM, Ota S, et al. Sleep and fatigue and the relationship to pain, disease activity and quality of life in juvenile idiopatic arthritis and juvenile dermatomyositis. Rheumatology. 2011;50(11):2051-60

61. Lelieveld OT, Armbrust W, van Leeuwen MA, Duppen N, Geertzen JH, Sauer PJ, et al. Physical activity in adolescents with juvenile idiopathic arthritis. Arthritis Rheum. 2008:59(10):1379-84.

62. Bohr A, Nielsen S, Müller K, Pedersen FK, Andersen FK. Reduced physical activity in children and adolescents with juvenile idiopathic arthritis despite satisfactory control of inflammation. Pediatr Rheumatol. 2015;13:57. doi:10. 1186/s12969-015-0053-5.

63. Klepper SE, Darbee J, Effgen SK, Singsen BH. Physical fitness levels in children with polyarticular juvenile rheumatoid arthritis. Arthritis care and research : the official J Arthritis Health Professions Association. 1992;5(2):93-100.

64. Takken T, Hemel A, van der Net J, Helders PJ. Aerobic fitness in children with juvenile idiopathic arthritis: a systematic review. J rheumatol. 2002; 29(12):2643-7

65. Van Pelt PA, Takken T, van Brussel M, de Witte I, Kruize AA, Wulffraat NM Aerobic capacity and disease activity in children, adolescents and young adults with juvenile idiopathic arthritis (JIA). Pediatr Rheumatol. 2012;10:27.

66. Alkady EAM, Helmy HAR, Mohamed-Hussein AAR. Assessment of cardiac and pulmonary function in children with juvenile idiopathic arthritis. Rheumatol Int. 2012;32:39-46.
67. Dencker M, Wollmer P, Karlsson MK, Lindén C, Andersen LB, Thorsson O. Body fat, abdominal fat and body fat distribution related to VO(2PEAK) in young children. Int J Pediatr Obes. 2011;6(2-2):e597-602. doi:10.3109/ 17477166.2010 .526612

68. WHO Report on the Global Tobacco Epidemic, 2009: Surveys of adult tobacco use in WHO Member States

69. Rosenthal SL, Passo MH, Lovell DJ, Nash AA, Britto MT. Substance use among adolescents with juvenile rheumatoid arthritis. Arthritis Care Res. 1998;11(5):391-6.

70. Surís J, Michaud P, Akre C, Sawyer SM. Health risk behaviors in adolescents with chronic conditions. Pediatrics. 2008:122:e1113-8.

71. Satija M, Yadav TP, Sachdev N, Chhabra A, Jahan A, Dewan V. Endothelial function, arterial wall mechanics and intima media thickness in juvenile idiopathic arthritis. Clin Exp Rheumatol. 2014;32(3):432-9.

72. Kimball TR, Daniels SR, Khoury PR, McCoy CE, Dolan LM, Urbina EM. Relationship between elevated arterial stiffness and increased LV mass in adolescents and young. AdultsJPediatr. 2011;158(5):715-21.

73. Lowenthal A, Evans JMA, Punn R, Nourse SE, Vu CN. Popat RA, Tierney ESS Arterial applanation tonometry: feasibility and reproducibility in children and adolescents. Am J Hypertens. 2014;27(9):1218-24.

74. Juonala M, Viikari JSA, Laitinen T, Marniemi J, Helenius H, Rönnemaa T, et al. Interrelations between brachial endothelial function and carotid intimamedia thickness in young adults: the cardiovascular risk in young Finns study. Circulation. 2004;110:2918-23.

75. Mitchell GF. Arterial stiffness and wave reflection: biomarkers of cardiovascular risk. Artery res. 2009:3(2):56-64.

76. Slyper AH. Clinical review 168: what vascular ultrasound testing has revealed about pediatric atherogenesis, and a potential clinical role for ultrasound in pediatric risk assessment. J Clin Endocrinol Metab. 2004;89(7):3089-95.

77. Lianza AC, Aikawa NE, Moraes JC, Leal GN, Morhy SS, Andrade JL, et al. Long term evaluation of cardiac function in juvenile idiopathic arthritis under anti-TNF therapy. Clin Exp Rheumatol. 2014;32(5):754-9.

78. Gow R, Silverman ED, Luy L, De Freitas C, Stamato T, Laxer RM, et al. Prevalence of cardiac manifestations of juvenile ankylosing spondylitis. Am J Cardiology. 1995;75:744-6.

79. Huppertz H, Voigt I, Muller-Scholden J, Sandhage K. Cardiac manifestations in patients with HLA B27-associated juvenile arthritis. Pediatr Cardiol. 2000; 21(2):141-7

80. Oguz D, Ocal B, Ertan U, Narin H, Karademir S, Senocak F. Left ventricular diastolic functions in juvenile rheumatoid arthritis. Pediatr Cardiol. 2000; 21(4):374-7.

81. Argyropoulou Ml, Kiortsis DN, Daskas N, Xydis V, Mavridis A, Efremidis SC, et al. Distensibility and pulse wave velocity of the thoracic aorta in patients with juvenile idiopathic arthritis: an MRI study. Clin Exp Rheumatol. 2003; 21(6):794-7

82. Bharti BB, Kumar S, Kapoor A, Agarwal A, Mishra R, Sinha N. Assessment of left ventricular systolic and diastolic function in juvenile rheumatoid arthritis. J Postgrad Med. 2004:50(4):262-5.

83. Pietrewicz E, Urban M. Early atherosclerosis changes in children with juvenile idiopathic arthritis Polski merkuriusz lekarski. organ Polskiego Towarzystwa Lekarskiego. 2007;22(129):211-4.

84. Vlahos AP, Theocharis P, Bechlioulis A, Naka KK, Vakalis K, Papamichael ND, et al. Changes in vascular function and structure in juvenile idiopathic arthritis. Arthritis Care Res. 2011;63(12):1736-44.

85. Koca B, Kasapcopur Ö, Bakari S, Celic E, Calay Ö. QT dispersion and cardiac involvement in patients with juvenile idiopathic arthritis. Rheumatol Int. 2012:32:3137-42.

86. Abul MH, Erguven M, Ozben B, Ayhan YI. The forgotten chamber: rightventricular functions in juvenile idiopathic arthritis. Pediatr Cardiol. 2012;33: $793-43$. 